\title{
7 \\ Empirical Tests of Moral Conflict for the Religious Public
}

In the previous chapter I concluded that there is no evidence for systemic knowledge conflict but that there is evidence for propositional knowledge conflict. Existing academic research on American religion, as well as existing research on what the public thinks about science and scientists, suggests that a more likely conflict is over morality, not knowledge. In this chapter I turn to new evidence for moral conflict between religion and science among the U.S. public. Due to the dominance of the idea of systemic knowledge conflict among academics, including the sociologists who design nationally accessible surveys, data concerning moral conflict are extremely limited, so most of the data I will use are indirect. What is needed to reach more confident conclusions are new survey questions, along with new qualitative research, that focus on moral conflict. My hope is that the results are suggestive enough that future scholars take up this topic.

The analyses in the previous chapter ruled out the idea of irreconcilable and complete conflict over knowledge and morality. The analysis of whether the respondent wants their daughter to be a scientist is the most persuasive-if a respondent believed that all of science was irredeemably immoral, they would not want their daughter to be a scientist. However, this was not the case, and what we have is partial moral conflict. Those religious groups who have moral conflict with science either think that there are some types of science that do not have this conflict and/or that no type of science is inherently corrupt, because a person with good morals, such as their daughter, can remain a good person within science.

Religious people are in moral conflict over multiple aspects of modern science. The first is over which institution will be looked to to set the meaning and purpose of society. The second is more specific-that religious people are opposed to 
the implicit moral teachings of some scientific claims. The third is not about fact claims about scientific research per se, but about the technology that such research produces.

\section{FAITH IN SCIENCE VS. FAITH IN RELIGION}

Science is more than simply facts. It can also be a source of societal hope-a way to save our society from its troubles, in the same way that societies have looked to other saviors, like religion. That is, people can have "faith" in science, with faith being defined as a "firm belief in something for which there is no proof." There is a lot of proof offered that molecules are made of atoms but very little proof that science will solve the world's problems. To believe that science will solve the world's problems, people have to rely upon faith in science as an institution, and there are competing institutions that they could have faith in.

Religious elites have upon occasion engaged in this conflict when they see scientists claiming that science can set the values and aims of society. As discussed in Chapter 4, the origins of the field of bioethics are in theologians' reactions to scientists trying to determine societal values. For example, inventor of in vitro fertilization Robert Edwards claimed that "moral laws must be based on what man knows about himself, and that this knowledge inevitably comes largely from science." 2 This is the type of view opposed by theologian Paul Ramsey, also described in Chapter 4, who claimed that scientists of the 1960 s were not engaged in "an exact science as such, but a religious view of where and how ultimate human significance is to be found." 3

The extent to which a population has such a faith in science obviously has important ramifications. For example, if people have faith in science to provide a source of direction that humans should aspire to, then scientists would be looked to to set societal goals. Survey analyses suggest that religious people are in the greatest moral conflict with science when science is portrayed as something to have faith in.

The GSS Survey I used in the last chapter has a question that can be interpreted as measuring the degree to which the respondent has faith in science as providing meaning and direction for society. ${ }^{4}$ The survey contains a block of questions with five-point responses, ranging from "strongly agree" to "strongly disagree," prefaced by the statement: "How much do you agree or disagree with each of these statements?" The first statement is "we believe too often in science, and not enough in feelings and faith." 5 This is a measure of faith in science's ability to provide meaning and direction for society. ${ }^{6}$

To examine whether religious citizens are less likely to have this type of faith in science, I defined religious groups as I did in the analyses in the last chapter. Analogously to the previous analyses, if members of a religious group are more 
likely to say that we should believe in feelings and faith than the nonreligious, I interpret that to mean that the religious group is in this particular type of moral conflict with science.

The first line in Table 3 shows the probability of a respondent from a group agreeing or strongly agreeing that "we believe too often in science, and not enough in feelings and faith." The general pattern in the results is clear. Controlling for demographic variables, every religious group has less faith in science producing meaning than do the nonreligious. It is conservative Protestants who have the least amount of faith in science compared to the nonreligious, with an enormous difference between the literalist conservative Protestants and the nonreligious. The odds of a nonreligious person agreeing is 32 percent, but for a literalist conservative Protestant it is 62 percent. In general, the religious respondents, compared to the non-religious respondents, do not want science to set meaning in society, which is a high-level moral conflict.

As a comparison, we can examine religious faith in science's ability to solve concrete problems in the world through technology. The survey also asked the respondent to evaluate whether "modern science will solve our environmental problems with little change to our way of life." Solving environmental problems would be consistent with the morality of all of the religions I can measure in this survey, so this question is measuring faith in technologies without religious valence, but not faith in science's ability to set meaning.

In the second row of Table 3, we see that it is only African American Protestants who have less of this type of faith in science. I can only speculate that African Americans have a different experience with environmental problems than do other Americans. But, more critically for my claims, the other religious groups are not different from the nonreligious to the extent that they have faith that modern science will solve this concrete technological problem. In sum, religious Americans, and conservative Protestants in particular, are very likely to think society puts too much faith in science and not enough in religion. They are in conflict over setting the meaning for society. This interpretation is supported by comparing this result to faith in solving a concrete problem like pollution, where most religious groups and the nonreligious have the same amount of faith.

\section{OPPOSITION TO THE MORAL STANCE OF SCIENTISTS}

The second type of moral conflict is more specific, and is that religious people are opposed to the implicit moral teachings of some scientific claims. These moral teachings can be intended by scientists, such as when they use science to justify a moral position, or they can be unintended. As an example of the unintended, conservative Protestants have long claimed that people exposed to evolutionary ideas are going to make certain moral connections regardless of what scientists 


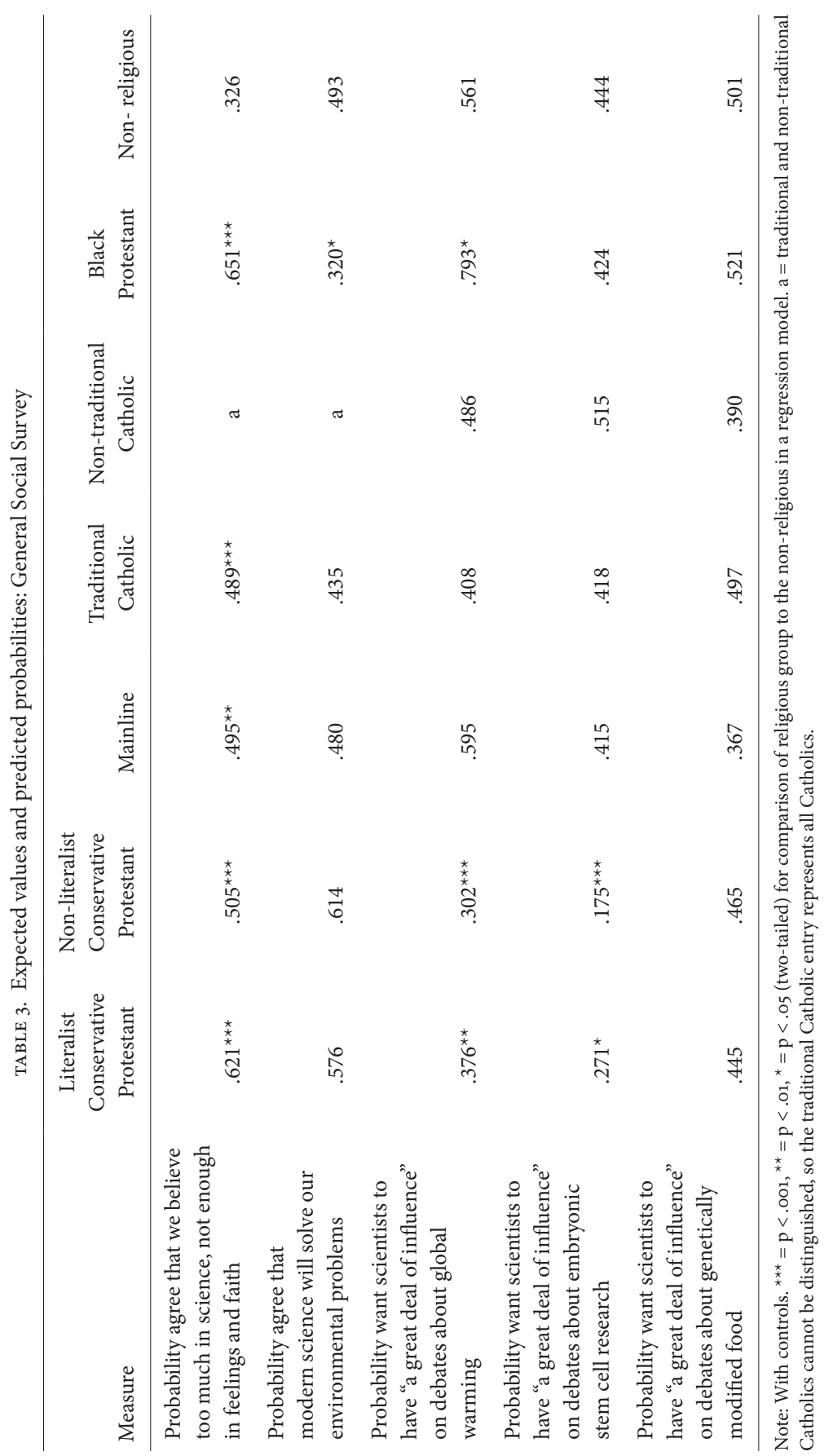


may intend. One claim is that if high school students learn that humans evolved due in part to random events, they will conclude that morality is random, even if a scientist never says anything about morality.

Similarly, religious elites have long been concerned that certain biomedical technologies implicitly teach the public that humans are defined by their biology, not by being made in the image of God. They believe that if we learn we are biological beings we will treat each other slightly worse than we would if we consider ourselves to be made in the image of God. I show elsewhere that members of the public who think that humans are defined by biology do indeed advocate treating people in a way that is more similar to the way we treat objects. ${ }^{8}$ Below I will conduct a number of survey analyses that suggest that conservative Protestants see this type of moral conflict with science.

\section{Opposition to Scientists' Influence in Public Debates}

If there is this type of moral conflict, members of religious groups will not want scientists to be influential in public debates about moral issues, independent of their view of scientists' ability to generate true knowledge. I can test this with survey data, continuing the analysis of the GSS data. To evaluate opposition to scientists' influence on moral debates in the public sphere, I use three questions that asked how much influence should: environmental scientists "have in deciding what to do about global warming"; "medical researchers" have on "government funding for stem cell research"; and "medical researchers" have in deciding whether to "restrict the sale of genetically modified foods. "I will generalize and call these three groups of professionals "scientists."

The first two of these issues are currently framed in the U.S. public sphere as moral debates. At first glance the global warming debate concerns whether it is occurring at the hands of humans. But, the reason that scientific claims about climate change are contested is that conservatives do not want to have to change our society's behavior. They do not want to drive smaller cars, make smaller houses, avoid airplanes, stop mining coal and so on in order to mitigate global warming. At its extreme, climate change deniers see scientific claims as part of a "hoax" or even a conspiracy to install liberal values regarding consumption, as revealed by the "Climategate" incident, in which conservatives claimed scientists were manipulating data. ${ }^{10}$ Climate change is at its heart a moral debate. What we should do about stem cell research is connected with the abortion issue, and its morality is constantly debated.

There is almost no moral debate on the final issue, genetically modified food, in the U.S. (although there is such a debate in Europe.) Rather, the moral issue is settled-if it is determined to be safe, then it is acceptable. The survey question itself poses the issue as one of evaluating risk, not morality, which makes the 
question about scientific influence over a public debate about facts and knowledge. This final question then serves as an effective comparison because it asks about scientific influence on a question not currently framed as implicating morality.

If conservative Protestants are opposed to scientific influence in first two debates, but not the third, this suggests that conservative Protestants are not opposed to scientists' influence on all debates. They are only opposed to influence on moral debates. This is consistent with seeing scientists as a group they are often in moral conflict with, and that they then have an interest in keeping out of these moral debates. They would have no problem with scientists' participation in the public sphere if it is not framed as moral, but about knowledge-limited to making technical assessments (e.g., whether genetically modified food is safe).

The analyses control for the same variables as in previous GSS models. They also control for the extent the respondent thinks scientists understand global warming or stem cells and the respondent's understanding of the methods of science, which should account for any effect of not wanting scientists to be influential because the respondent disagrees with the science per se. I also use two measures of wanting other professional groups to be influential in the debate to control for not wanting anyone to be influential in a public debate. ${ }^{11}$

The third and fourth lines in Table 3 show that the literalist and nonliteralist conservative Protestants are more opposed than are the nonreligious to the influence of scientists on public moral debates over global warming and stem cells. ${ }^{12}$ For example, nonliteralist conservative Protestants are only about half as likely as the nonreligious to want scientific influence in these debates.

Importantly, the final line in Table 3 shows that for genetically modified food, no religious group is different than the nonreligious in wanting scientists to influence these debates. This means that there is not an opposition to scientific influence in the public sphere in general-to, for example, giving advice on knowledge issues. There is only a religious opposition to scientists influencing public debates about moral issues.

I later repeated the same analysis for wanting scientists to be influential in debates about global warming but while also controlling for political identification and political ideology, which allows us to separate out any religious effect from a political effect. ${ }^{13}$ In that analysis (not shown), the most powerful predictors of not wanting scientists to be involved in the public debate are not believing that scientists understand climate change, not wanting the influence of politicians, and identifying as a Republican. ${ }^{14}$ This suggests a generally political explanation for not wanting scientific influence on this one issue.

However, even after controlling for these political variables, literalist conservative Protestants are still less likely to want scientists involved in this debate. This difference between literalist conservative Protestants and the nonreligious is not large. However, it is striking that there is a difference at all. While global warming 
is moral, it is not an issue that has particularly religious valence in the same way that embryonic life does. The small religion difference here is indicative of the fact that these conservative Protestants do not want scientists involved in any moral issue, not just the ones where the morality of conservative Protestantism and science are thought to differ.

\section{Is the Scientific Community Self-Interested?}

In 1942 sociologist Robert Merton described the four "norms of science:" universalism, communism, disinterestedness, and organized skepticism. ${ }^{15}$ Universalism means that truth claims are subject to impersonal evaluation, regardless of who the scientist making the claim is. Communism means the findings of science belong to the community. Disinterestedness means that scientists do not make personal gain from their work. Organized skepticism means not making conclusions until data are at hand, and that all claims are subject to empirical and logical critique. In a later critique of the "norms of science," sociologist Michael Mulkay described a longer list that included additional norms that had been created by scholars standing on Merton's shoulders: "rationality, emotional neutrality, universalism, individualism, disinterestedness, impartiality, communality, humility, and organized skepticism." ${ }^{16}$ Merton and those in his intellectual lineage took these norms to be how scientists actually operated.

If this is what scientists are like, then it is hard to see how science and scientists could have a moral agenda. However, by the late 196os, critics were pointing out that these norms are actually not in force among scientists, and Mulkay concluded that the Mertonian norms were not norms, but rather an ideology. Scientists only describe themselves in this way to justify "their claim for a special political status." Moreover, this "biased image of science ... supports their collective interests [and] amounts to the utilization of an occupational ideology" ${ }^{17}$ This depiction of scientists is more consistent with scientists having a collective moral agenda.

I lack a measure of whether the public perceives scientists to be observing each of these norms. However, a series of GSS survey questions did ask respondents if they thought scientists were acting in their own self-interest. Respondents were asked "when making policy recommendations about global warming, on a scale of 1 to 5 , to what extent do you think the following groups would support what is best for the country as a whole versus what serves their own narrow interests?" Best for country is " 1 " and narrow interests is " 5 ." They were asked similar questions about stem cell research and genetically modified foods. For each technology respondents were asked about the self-interestedness of scientists plus two other groups. ${ }^{18}$

These questions effectively measure the extent to which scientists are perceived as working in the nation's interest or their own collective interest. Believing that scientists have a distinct agenda from the rest of society is a prerequisite for thinking 
that scientists have a distinct morality that should be opposed in the public sphere. Therefore, if members of a religious group are more likely than members of the nonreligious group to think that scientists are not acting in the nation's interest, I consider that evidence for moral conflict of that religious group with science.

The evaluations of the self-interestedness of scientists for global warming and stem cell research were combined into an overall "self-interestedness" measure. ${ }^{19}$ For technical reasons, the responses to the question about genetically modified foods had to be analyzed separately. ${ }^{20}$ I needed to find a way to account for the fact that conservative Protestants are more likely than others to think that any group is self-interested-or, more theologically, that everyone is sinful. I therefore control in the statistical models for thinking other groups that the survey asked about were self-interested, to see if respondents think that scientists are particularly self-interested. ${ }^{21}$

As in previous analyses, the regression models also control for demographics. The analytic question is, as before, are particular religious groups likely to think that scientists are self-interested when they enter the public sphere, even after controlling for the extent to which the respondent thinks that all groups are selfinterested? The results shown in the first row of Table 4 suggest that both literalist and nonliteralist conservative Protestants are much more likely than the nonparticipants in religion to say that scientists are working for their own and not the country's interests. ${ }^{22}$ No other religious groups are different from the nonreligious.

On the other hand, the second row shows that there are no differences between religious groups and the nonreligious on thinking scientists are self-interested on genetically modified food. This is consistent with the earlier findings about wanting scientists to be influential in the public sphere. That is, on the two issues that are constructed as moral issues in the U.S.-global warming and embryonic stem cell research-conservative Protestants think that scientists are forwarding their own and not the public's interests. But, this is not the case for the one issue that is constructed as being about knowledge-genetically modified foods.

Similarly, in 2012, the GSS asked about the level of agreement with the statement "Scientific researchers are dedicated people who work for the good of humanity." ${ }_{23}$ This produces an image of disinterested scientists forwarding the consensual morality. The analysis shows that the probability that a nonreligious respondent will not strongly agree that scientists work for the good of humanity is high, at .769. There is clearly generalized skepticism about scientists among the entire public. The probability for a literalist conservative Protestant is even higher, at .869. (see the third row of Table 4.) That is, despite only 443 people being asked this question, making it less likely that any difference would be statistically significant, literalist conservative Protestants were more likely than the nonreligious to disagree that scientists work for the good of humanity. In sum, these survey analyses suggest that conservative Protestants are more likely than the nonreligious 
to think that scientists are working in their own self-interest. While this is not morality per se, it suggests that conservative Protestants do not think scientists are neutral investigators of nature.

\section{MORAL CONFLICT OVER TECHNOLOGY}

The third type of moral conflict is not a moral objection to scientific research per se, but rather to the technology that scientific research allows. Technology is "the application of scientific knowledge for practical purposes," so medicine and engineering are technologies. ${ }^{24}$ While it could be argued that science is distinct from technology, I doubt the general public sees a distinction between, for example, scientists and medical researchers or scientists and engineers.

Technology has even more direct moral implications because it is applied to the social world. And there is a moral critique of almost every technology we can imagine: automobiles, airplanes, television, the internet, nuclear energy, and on and on. However, most technologies do not have a particularly religious valence, and Western religions do not have a problem with technology per se.

But, there are some technologies that do have implications for religious beliefs and morals. While the computer is religiously neutral, the Christian religion at least is in general centrally concerned with the human body-particularly reproduction and sexuality. ${ }^{25}$ Therefore, technologies that concern the body, life, and death are those most likely to have moral implications for Christians. Technologies that concern human embryos and the hastening of death, as well as human genetic engineering, reproductive genetic technologies, pregnancy, childbirth, organ transplantation, and human enhancement are all examples that are probably seen by religious people as having moral implications. We are all familiar with public debates about these technologies and that religious people are often front and center in these debates.

Below I conduct quantitative and qualitative analyses that show that religious people are not opposed to technology itself, nor are they opposed to manipulating the human body. For example, they do not think that manipulating the human body is "playing God." Rather, they think, to use the phrase of the late Paul Ramsey, that we should "play God as God plays God" with nature and the human. ${ }^{26}$ The question is moral-what is the appropriate version of playing God?

Moreover, opposition to a technology by religious people is never about knowledge. For example, if you look at the papal documents that argue for the sanctity of human embryos, and thus that abortion, most reproductive genetic technologies, and embryonic stem cell research are all morally wrong, these documents accept and use the latest scientific research on embryos. ${ }^{27}$ It was embryology, after all, that taught the institutional church about what exactly happened at fertilization. The Catholic Church just reaches a different moral conclusion from the scientific facts than most scientists do. ${ }^{28}$ 
In another example, in an earlier book I engaged in an in-depth interview study of 180 largely religious Americans to discern their views of reproductive genetic technologies such as pre-implantation genetic diagnosis, human genetic engineering, and cloning. In general, these religious citizens were more opposed to these technologies than were the nonreligious people. In the analysis of all of those interview transcripts, I do not remember an instance of a respondent, including the fundamentalists, challenging the scientific claims behind any of these technologies. It was just accepted that the science was accurate. They did have a moral analysis of those facts that often conflicted with the moral analyses given by the proponents of these technologies. ${ }^{29}$

\section{Growing Moral Conflict Between Conservative Protestantism and Technology Applied to the Body}

It is quite easy to show that conservative Protestants and conservative Catholics are more opposed than are the nonreligious to many technologies that involve the human body, like embryonic stem cell research. It is a greater empirical challenge to show that they see their opposition to embryonic stem cell research to be part of a moral conflict with scientists. Below, I infer this moral conflict through an evaluation of changes in the level of confidence in scientists from 1984, when the available data begins, to $2010 .{ }^{30}$ Over this time period, scientific innovation shifted to the human body-at the same time that religious conservatives were also shifting attention to the human body. Thus, moral conflict.

In the 1950 s and 1960s, conservative Protestants were involved with anticommunism, and in the late 1970s, they joined conservative Catholics in the religious right movement. While the original motivation of the religious right was to defend its schools from what it saw as government interference, it later began to take positions on issues like abortion, homosexuality, and sexual ethics, later turning to euthanasia and embryonic stem cell research..$^{31}$ These questions of the body, and particularly reproduction and female sexuality, have always been central to the Christian tradition. ${ }^{32}$ They had just had not previously been as central a part of public debate.

The public face of science was changing at the same time, making it more likely that conservative Protestants would see science as a competitor in moral debates about the body. The scientific issues in the public sphere from the 1950 s through the 1970 s were nuclear energy, pollution, weapons, and the genetic modification of micro-organisms. These were not generally thought of as "religious." However, by the 1970s, science began to debate issues having to do with the human body such as abortion, birth control, human genetic engineering, organ transplantation, the definition of death, euthanasia, mind control and, later, embryonic stem cell research and cloning. These could be seen as part of the moral agenda of scientists, 
but these were traditionally more "religious" issues. By the mid-1970s theologians and scientists were solidly engaged in clashes over the morality of these technologies in the emergent public bioethical debate..$^{33}$

Therefore, a growing moral conflict with science could have resulted from this change in the social priorities of both conservative Protestants and scientists, as both groups began to make often conflicting moral claims about the human body in the public sphere. If so, it should also be the case that conservative Protestants have become increasingly opposed to the moral influence of scientists since $1984 .{ }^{34}$

I focus on the respondents' response to the question: "I am going to name some institutions in this country. As far as the people running these institutions are concerned, would you say you have a great deal of confidence, only some confidence, or hardly any confidence at all in them? Scientific community." This question is not framed as asking the respondent for an evaluation of the legitimacy of the methods of science. The wording and context of the question clearly indicate that it is read as the view of the social influence of science as an institution in the public sphere. ${ }^{35}$ When asked for their level of confidence in the scientific community, 43 percent of the respondents replied "a great deal," fifty percent replied "only some," and seven percent replied "hardly any." I conducted analysis by comparing those who said "a great deal" to those who said "only some" or "hardly any."

As with the analyses above, I controlled for the demographic qualities and political orientation of the respondent and used regression models to see what characteristics of a respondent predict responses to this "confidence in scientists" question. ${ }^{36}$ As you might imagine, one of the strongest predictors of confidence in science is confidence in any institutions about which the GSS asked. People who do not trust one set of elites usually do not trust any elites. That is not especially interesting but is important to account for in any analysis, given that conservative Protestants may be inclined not to trust elites in general.

More important to my interpretation is to show that people do not lack faith in the leaders of science simply because they think that the methods of science are wrong or that science does not generate accurate truth claims. That would be knowledge conflict. To ensure that I am not measuring knowledge conflict, we can see if those who have avoided science (as I measured in the analyses described in Chapter 6) have less confidence in scientific elites. I looked to see whether people who knew more uncontested scientific facts, claimed more knowledge about science, knew more scientific methodology, had taken more college level science classes, or had a scientific occupation had more confidence in the leaders of scientific institutions. None of these factors have any influence on what the public thinks about scientific leaders, so their confidence in institutional science is not about true or false knowledge.

A stronger test is whether those people who believed in the conservative Protestant claims about human origins had less confidence in scientific elites. 
This would mean that the lack of confidence was about a knowledge conflict over human origins. I used the same measure introduced in Chapter 6 that measures belief in this contested knowledge. Here again there is no difference in confidence in scientists between those who agree more with the scientific versions of human origins versus those who agree less with the scientific version of human origins. Confidence in scientific institutions in the U.S. appears to have nothing to do with knowledge claims at all. While I make this point in service of larger claims below, it is itself further evidence for a lack of systemic knowledge conflict in the contemporary U.S.

Further analysis shows that, consistent with the general narrative of this book, confidence in science for the entire public - not just the religious - is at least partly based on morality. There were few appropriate survey questions available, but I was able to use the question from the previous analyses in this chapter, where the respondents were asked whether they wanted scientists to be influential in debates about embryonic stem cell research. ${ }^{37}$

Even after controlling for all of the knowledge measures and demographics, there is a quite large difference in confidence in the scientists between those who are opposed to scientists' influence on stem cell research and those who are supportive of this influence. The analysis, not otherwise shown, reveals that similarly situated respondents who want little to no influence of scientists in debates about stem cell research have a one in four chance of saying they have confidence in the scientists running the institution of science. Those who want a great deal of influence of scientists on stem cells have a one in two chance. Confidence seems quite highly structured by how much the respondents want scientists to be involved with moral debates in the public sphere, so I will treat this confidence measure as a proxy for moral conflict.

I continued the analysis to see if the lack of confidence in elite scientists was influenced by religion, even after controlling for variables indicating exposure to science. It is. The last row in Table 4 shows that a literalist conservative Protestant has only a fourteen in one hundred chance of having confidence in scientists, whereas the nonreligious have a thirty-eight in one hundred chance. There are no other differences by religion. Moreover, additional analyses show that if someone is opposed to scientific influence on embryonic stem cell research and is a literalist conservative Protestant, they have even less confidence in elite scientists. ${ }^{38}$

In sum, for the entire public, confidence in the scientists who run American science institutions appears to be driven by moral evaluation of the scientists, not by opposition to the knowledge claims made by science. This is particularly true for conservative Protestants. Has this moral evaluation of scientific elites changed over time? If so, we can infer what the moral conflict may be about.

If we look over time, we see that the level of confidence by most religious groups has remained constant over time. For example, mainline Protestants were slightly 


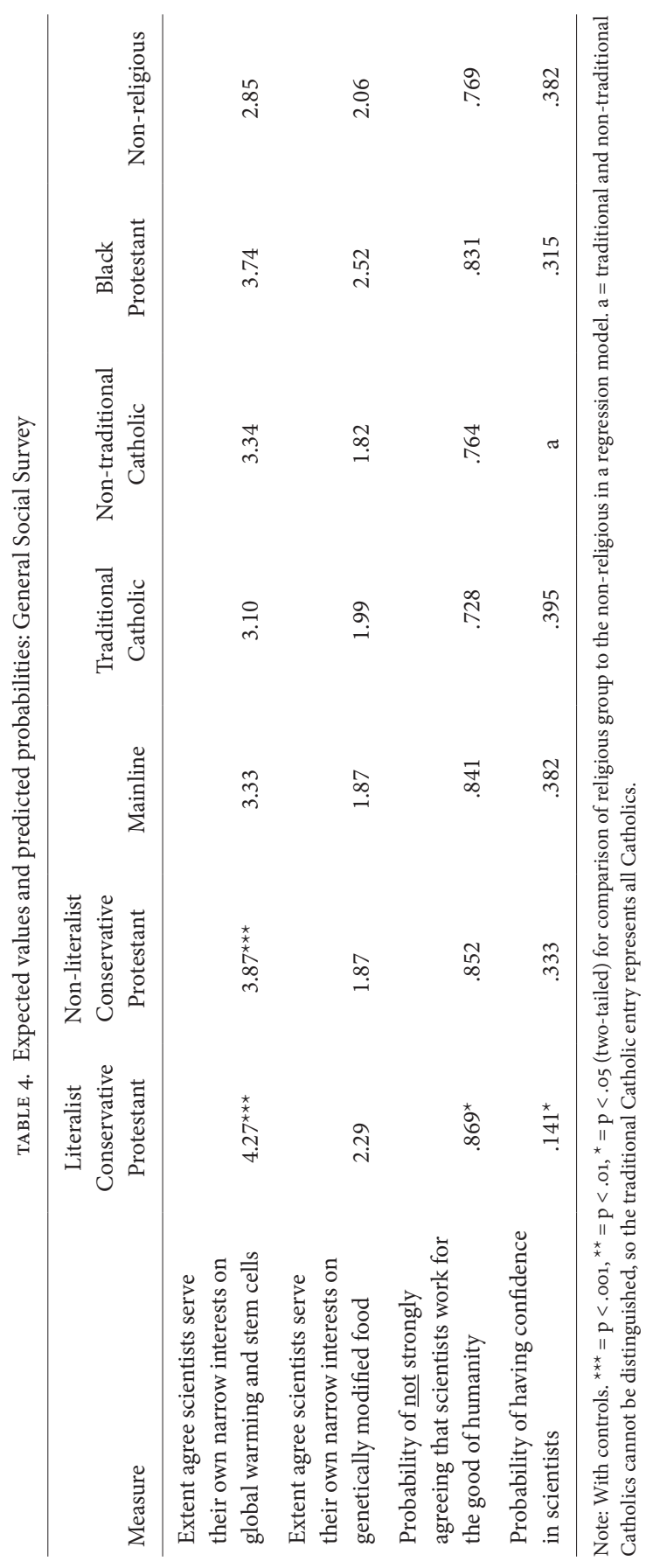


less confident in scientists in 1984 then were the nonreligious, and they are equally less confident in 2010. The one difference is for literalist conservative Protestants, who have become even less confident over time. ${ }^{39}$ In 1984, the difference in odds between literalist conservative Protestants and the nonreligious was only .10, but by 2010 the gap had about doubled.

We can then ask what has changed socially or morally for science and/or conservative Protestantism between 1984 and 2010 to cause this increased level of conflict. Here I run out of available survey questions, and it is my hope that if social scientists become more attuned to moral conflict, they will begin to incorporate questions into future surveys. But, I believe the answer is, as described above, that during this time period both science and religion moved from concern with the physical world toward concern with the human body, which has long been a moral focus of Christianity.

\section{Religious Views of Engineering the Human Species}

I finish this chapter by trying to more precisely describe religious Americans' view of technology, so that we can see possible present and future moral conflict with science. I focus on one of the technologies with a great deal of potential religious implications-genetic modification of the human species.

I lack data on the views of the scientific community concerning genetic modification or, more importantly, what the religious public thinks the view of the scientific community is. I examine in-depth interview data with religious Americans that allow us to imagine what points of consensus and conflict would come into being if the scientific community is seen as taking various positions in the years ahead. The most obvious conflict would be if the scientific community is seen to be on the side of "improving" the human species, as it was in the eugenics movement. However, we need to see that there would be many points of consensus that may surprise many. I will make the following points about the moral views of religious Americans.

First, far from being opposed to applying technology to the human body, religious Americans see technology as a source of hope and an engine of human progress. However, religious people have ethical concerns about the end goal of this progress. They would be opposed to the use of this technology for creating an improved human species beyond what it is "supposed" to be. For the religious, the goal for these technologies should be to restore the nonsuffering human, not create a super-human.

Second, common wisdom is that religious people are opposed to modifying the human genome to improve the species, because God created humans as they should be. I will argue that this is not correct, and that the majority of religious people are not opposed to genetically modifying the human species per se. They 
do not view the current human genome as somehow sacred and not to be "tampered with." That is not where any moral conflict lies.

Third, in actuality, religious people think we have an obligation to use technology to transform the world and even the human body. The difference with much of the scientific ethical thought on this issue is that the religious believe we should not use our own vision to make the blueprint for the future, but should instead determine what God would want us to do. This subtle difference could result in future conflict if technological abilities improve.

I conducted an inductive discourse analysis of responses from an in-depth interview study that focused on what religious people in the U.S. think about reproductive genetic technology ${ }^{40}$ The interviews began with a series of hypothetical scenarios about couples who are planning on having children, and I asked the respondent what advice they would give the couple. The first scenario was about a couple who had found that they are both carriers for cystic fibrosis. "What should they do?" the respondent was asked. In the next scenario, the woman is already pregnant, and they are offered amniocentesis possibly followed by abortion. "Should they do this?" the respondents were asked. In the next scenario, a couple is offered pre-implantation genetic diagnosis to avoid cystic fibrosis. ${ }^{41}$ Another couple are offered pre-implantation genetic diagnosis for early onset Alzheimer's disease, and another for deafness, and yet another are offered pre-implantation genetic diagnosis to avoid having an obese child. Finally, a hypothetical couple is offered pre-implantation genetic diagnosis to obtain the smartest child possible. Another scenario involves sex selection, and another sperm sorting to determine the gender of the baby. The scenarios then turn to germline human genetic engineering to engineer traits such as cystic fibrosis, obesity, and intelligence in an embryo that eventually becomes a child-and thus that trait would be found in all of that child's descendants. A final scenario asks about reproductive cloning. Questions then turn to what the respondent thinks the effect of these technologies will be on society, some questions about religion, and finally how the respondent thinks our society should have a debate about reproductive genetic technologies. ${ }^{42}$

The questions I primarily focus upon here were near the very end of the interview after an hour or more of conversation about religion and reproductive genetics. The typical conversation by that point has been, at least for the religious respondents, interwoven with religious discourse, and due to the priming early in the interview, many responded with religious reasons for and against the use of these reproductive genetic technologies.

The first of the questions I examine occurred at the very end of the interview. It was different than the previous questions, in that the interviewer handed the interviewee a card that had ten words listed in a column on it, and the interviewee was asked, "When you think about all the issues that we have talked about today, which one of these words best summarizes your feelings. Or, you can pick a word 
that is not on the list. Or, you can talk about more than one if you want." When the respondent would pick a word, they were asked, "Why that word?" It is in their reasons for picking that word that we can determine their moral vision for these technologies. The words on the card were humility, worry, fear, hopefulness, happiness, hopelessness, anger, helplessness, reverence, and awe. The other responses I focus upon in this analysis come from us asking, "Should the ability to change the genes of the human species be reserved for God?" This is designed to get to the question of who should modify and/or provide the design for future humans.

Let me start with the data generated from the word selection exercise, which helps me address my first point, that religious people in the U.S. generally see reproductive genetic technologies through a lens of hope. The question comes after extended discussions of technologies, some of which nearly all respondents are opposed to. For example, almost nobody was in favor of human cloning, with most people finding it repellent. The vast majority of respondents had some technologies and applications that they approved of, and some that they did not. Overall, what was the conclusion about reproductive genetics? Were they hopeful, and thus tended to ignore the "threat" of technologies like cloning and creating super-intelligent babies? Or, did they focus upon the negative, and see human bodily modification through genetics as a foreboding picture of our future?

I deductively coded the responses by the word selected, and then inductively coded the reasons given for selecting that word. There were certainly people who fit the stereotyped depiction of religious people seeing dread, with some selecting "worry," "fear," "worry and fear," "anger and fear," and "hopelessness." A few suggested their own word to summarize their thoughts about reproductive genetic technologies - "concern." The response of one of the Catholic respondents was typical. His word was "worry," and when asked why, he said "I would hate to see society come to the place where we can manufacture a human being the way we want it to be. That would be very worrisome to me."

Similarly, a mainline Protestant who approved of the individual use of many of the technologies talked through the other possibilities on the card. "Well, not 'happiness' or 'anger," he said. "I think probably 'fear' and 'worry' more than the 'hopefulness' reference and 'awe,' which probably reflects my cynicism more than anything else. But-I mean it could potentially be a very good thing, but human history being what it is, you know, when we meddle in these things, we tend to end up doing more harm than good. So, I think 'fear' and 'worry."'

However, these negative visions of the future of genetic modifications of humans were not the dominant response. The majority of words selected by conservative Protestants, mainline Protestants, and Catholics could be categorized as either "all good" or "good and bad." Mainliners were the most positive, with almost all selecting "all good" words or "good and bad" words. Conservative Protestants were a bit less positive, followed by Catholics. 
By far, the "all good" word most chosen by respondents was "hopefulness," and nearly everyone said the reason they selected that word was that we would soon be able to relieve the suffering of disease by using reproductive genetic technologies. As one mainline Protestant respondent put it:

I think hopefulness would be the selection that I would make. I get to thinking about it and think that we can contribute significantly through the development of these technologies to reduce human suffering. I can't imagine anyone not being hopeful about that. It's not going to be easy. It's going to be very complicated. We need to exercise humility in the process, but I don't find it hopeless or helpless. I'm hopeful.

Earlier, she was asked about a scenario in which a doctor could "fix the genes in a fertilized egg to remove the chance that any baby would have cystic fibrosis," so that "not only would this child be free of this gene, but so would the child's children, the child's grandchildren, and so on." She responded that she would be supportive of the use of this technology to change "the lineage," in her words, because "I think it's a great technique, if that exists, and I think it would be wonderful to eliminate cystic fibrosis from our world, and that will take some time to do, I'm sure."

A fundamentalist Protestant said he picked "hopefulness" because "I think we're on the verge of some good things for people for our society and hopefully we'll be able to handle these new technologies with wisdom. And if we're wise in what we do, we only improve society. If we're not wise, they're very dangerous. So I guess I'm hopeful that we'll be wise in the way we can handle them."

Earlier, in a discussion about using germline genetic engineering to remove cystic fibrosis from the family line, he was not concerned about the technology itself, only that it did not involve killing embryos or fetuses-a common response for conservative Protestants. "Sure, if that technology is available, certainly," they should use it, he said. When asked, "Do you have any concerns about this technology at all?" he said no, as long as "it's not done by replacing a gene with fetuses, that stem cell stuff." We can see the boundaries of his moral conflict with science.

A Catholic man said the choice of words was easy, and his choice was "hopefulness." The reason was "because we have within our grasp, like no other time in history the chance to eradicate so much human suffering. We're on the cusp of a great era of discovery and ... hopefully my children will live to see it. ... I remember getting ... polio shots and you know polio and small pox has been eradicated. Amazing things have .. . happened in my lifetime and my kids are going to see remarkable things."

Perhaps more interesting was the very common impulse to select a positive and negative word to indicate the good and the bad. The positive was always a word that they chose to represent the hope of the relief of suffering through genetic technology. The negative was a word to represent either fear of misuse (typically radical 
enhancements) or of forgetting that we humans are not God. The most common words selected together were "hopefulness" and "worry." One respondent stated, "Actually, two things kind of pop out. The hopefulness because I think that a lot of good could come from being able to control some really major medical problems and worry ... a little worry about just how far the scientific community would maybe want to go with the technology that they are developing or that they have."

Similarly, a mainline Protestant stated that "I would put hopefulness in there and I think I have to add worry." Hopefulness was selected because of "the good things that can happen with the technology that you have described," and worry was selected because "the technology could be ... misused for frivolous reasons." She was typical in her support for revising the human species to eliminate disease, but not for changes that she thought were not disease-based. She was in favor of germline genetic engineering for cystic fibrosis, as long as there were no "unforeseen consequences." The interviewer then began "what about for ..." and she interrupted with "for blue eyes ... no!"

Religious respondents often also selected terms of reverence and awe, signifying caution, that we are interfering, perhaps with good reason, in something that is far above our human perspective. Similarly, it was common for respondents to select "hopefulness and humility," with "humility" a reminder that we are not God. As one conservative Protestant put it, he selected humility "because it helps-you know, helps me realize that I'm not God. I'm not able to make perfectly correct decisions." He was hopeful, "because I think that this is a technology [that] will help people."

A smaller group of people selected "hopefulness" and "awe," with hopefulness for the prospect of curing disease, and "awe" meaning "at awe of our awesome technological abilities." A fundamentalist Protestant said he picked these words because:

I believe of course there is, you know, as we progress along as a society, there are things to be hopeful for that diseases will be eradicated and that people will live comfortable lives. You know, and an ultimate hopefulness of someday getting to Heaven and sitting face-to-face with the Creator. It is kind of awesome to think that we have this technology to be able to do some of these things, but I believe of course that credit should be given where credit is due. It's not necessarily us that are actually doing this. We're the clay in the potter's hands, even those that may not necessarily be someone who believes in Christ, because God certainly has the capability and power to do that. So I would say probably hopefulness and awe. Some of these more negative feelings, you know, I just don't see that. I for one, I'm certainly not worried or fearful.

Roughly equal numbers of religious people in each religious tradition selected "all good," "good and bad," and "dread" terms. There was a slight tendency for 
mainliners to be more "glass is half full and Catholics to be more "glass is half empty." For the "all good" category, these were people who, despite being opposed to some aspects of reproductive genetic technology, had an overall exclusively positive, hopeful vision for genetic intervention going forward.

Religious people in this study are not anti-science or anti-technology. By and large they do not see the human genome as sacred and thus inviolable. They believe in what they perceive as the relief of suffering, most notably through "medical" interventions. However, religious people in the U.S. seem to entirely lack a eugenic vision, where we intervene in the human genome to "improve" the species. Rather, the present-day healthy "walking-around" sort of human is the ideal, and the goal is to get everyone to that "normal" state. However, their positive vision going forward is largely tempered by a caution at what humans might do wrong. When future scholars closely examine any moral conflict between religion and science, I expect that they will find these subtle points of convergence.

Subtle differences between religion and science should also be expected to emerge. To the extent that scientists are more sympathetic with the idea of "improving" humans according to our own human definitions of quality, we can expect moral conflict. In contrast, one could imagine religious people in the U.S. in favor of creating a Humanity 2.0, as long as the blueprint was made by God. Again, the difference in these moral visions is not in their view of scientists' knowledge or abilities. Nor is the difference in their view of whether humans should change nature. On this they would agree. The difference is that the religious would try to get the moral principles behind any change from the "objective" source of God's will. The scientists would look to contemporary human values where, if the current culture values super-intelligence, than that is what Humanity 2.o should have.

I turn to my second point, which is that the religious are not opposed to modification per se, and my third, which is that humans are to enact this modification, not God. Religious respondents believe in modifying the current human, but want to constrain changes to those that would please God. Of course, an academic analyst could say that these people should recognize that what is thought to be "pleasing to God" is also a matter of social consensus, ultimately no different than simply polling a society. However, this is not how religious people see it.

The limitations on human improvement in the Western religious vision can be found in the elite theological discourse, where there is a strong dichotomy between God and humans. Humans are not God, but were created by God, along with all of "nature." A long-running part of Christian theology concerns what actions in the physical world are then the responsibility of humans, and which are to remain the province of God. This is represented by the theological debate concerning whether we humans are simply a created creature of God or co-creators with God. ${ }^{43}$

With a technology like the genetic engineering of humans, if we are purely creatures, God is entirely responsible for our human bodily form, and we are not 
to interfere. To take this to its logical conclusion, we should not heal diseases humans are born with, because God created them. However, if we are co-creators with God, we participate in fulfilling God's desires for the human bodily form. In this vision, God wants us to heal disease and relieve the suffering of an imperfect world and an imperfect human.

In the interviews, well after all of the questions about what people should do in the face of various genetic conditions, the respondent was asked: "Do you think that the ability to change the genes of the human species should be reserved for God?" The responses here point directly to the respondent's notion of whether we are co-creators with God and whether something like human genetic modifications should be something "left to God." We can also see what is left to God and what is left to humans and, to anticipate the conclusion, it is God's job to come up with the plan, and it is humanity's job to implement it.

A minority of religious people do say that yes, the ability to change the genes of the human species should be left to God, and these are typically the people who are opposed to all applications of all technologies. It is hard to imagine that they do not believe in the human modification of God's creation, because presumably they all believe in medicine, mechanized agriculture, and so on. I suspect that it is the intervention into the design of the human species that is particularly problematic for this group. I also suspect that this response is not an objection to technology itself, but rather that they can think of no morally acceptable application for the technology, so they oppose it by saying humans should not have the authority to do it.

It is hard to tell what these outright opponents were thinking, because they rarely gave their reasons, and just implied that it was obvious from their previous comments. The few who really articulated their reasons sound like the stereotypes of religious people as theological Luddites. The common wisdom would be that religious people would say that we "should not play God" with technologies, and one Pentecostal respondent seemed to agree, saying "yes," we should leave it to God, "because He created us . . . I don't think someone should change you just because they want you to be a certain way. . . . If God wants you to be better, then He will make you better. . . . No, I think it's up to God to do it, not to wait for scientists to put you out in a lab and you're sort of like a guinea pig or something. So I think it's up to Him. I mean, we're here. He made us a certain way for a reason."

However, the strong majority of religious respondents said "no," the ability to change the genes of the human species should not be left to God. There were three major reasons: that God works through humans; that we should transform the human if limited to good, God-given purposes; and that we have God-given free will to do both good and bad.

The first reason is well articulated by one Catholic respondent, who put it quite succinctly, stating that "He created the people and He helps people to create 
technology to change these things. I don't think it should be just God. . . . No, I think He's out there saying, you know, 'I hope you find a cure for cancer' or whatever." A mainline Protestant said that "We are God's hands on earth. So it's up to us to use it, not-God's not going to do it. [Normally], He's going to have us do it. So, it's our responsibility to use those techniques." Similarly, an evangelical responded that:

it goes back to the sense that God has given us these abilities and this intelligence to create penicillin to wipe out, not wipe out, but to be able to fight bacterial diseases, to create drugs that combat cancer and other disease. It gives me medicine to take for my thyroid to make it work right, and I think that is all good stuff. I think there can be good stuff coming out of genetics and genetic technology. But there is always the flip side of how that technology is going to be used. I mean, we create all these drugs, and we also create dangerous viruses that can be used as weapons. That is the flip side of everything. God has given us the ability, so ... I don't believe you can say, "Okay, God alone can do this," but on the other hand I believe you have to be willing to look at things as not just as a "What can I do?" but "What should I do? What is the right thing to do?"

The second common response is that genetic transformation should not be reserved for God, as long as we are doing God's will, which is obviously related to the first reason. A mainline Protestant respondent said that:

If it's something like medical science would determine that if they removed a gene and prevent someone from being born with the disease or could prevent disease from occurring in that child, yeah, I think that's great. Again, I look at that as medical science that knowledge . . . a God-given knowledge. It's not creating life . . . it's improving the quality of life. It's human life, but I think that's as far as I can go. But altering genes to make a superhuman being or, you know, making someone ... making a life, cloning, cloning a life to be something that wouldn't otherwise be naturally, I don't think that's within our purpose as human beings. I don't think it's our right.

An evangelical responded that "some of this genetic engineering is good and some of it's bad, but overall, I think He's given us the intelligence that I think our soul and our spirit-if the soul and the spirit's not lighted up with God, then that's where you get into trouble." We have to be doing it "from the right perspective ... and from God's perspective." Finally, a mainline Protestant said that:

It goes back again to, what are you going to do with it? Like, that's the big question in all of this. It's not so much that should you or shouldn't you do it. It's like once you learn how to do it, the genie is out of the bottle, right? You're never going to put him back in. What are you going to do with it, now that you're able to do this? Are you going to do things good for society and for humankind or use it for trivial things like picking kids' eye color. That's the question. 
The third reason is not so much that God's plan should be in control, but that we humans are on our own to select good and evil. We have free will. There is still good, and the respondent seems to know what it is, but this choice is part of the human condition. God is not a micro-manager. As one Catholic man said, "We're always going to be able to do miraculous things. We're always going to be able to go to the moon ... It's what we do with it and how we use it is where we stay connected to God. I think we're capable of dickering with just about anything we want to. That's just our nature, because we're that smart or that intelligent and we can. We have that free will."

Similarly, a conservative Protestant woman told us that "my belief is that the Lord has these things at our disposal or at our use, if needed, if necessary, and we make the choice of how we want to move with that. Do we want to use it-do we not want to use it? Why do we want to use it? I don't think it's an issue of are we going to upset God if we do it. Are we going to upset Him if we don't do it? No. I think these are the different options we have. What are we going to choose and what are we doing in making our choice?"

Yes, there are some religious people who are opposed to developing some technologies at all. I suspect that this is because they can think of no moral use for the technology, like a pacifist who could see no moral use for a weapon. Most religious people instead view scientific technologies like most people view guns. It is not that they should not exist, it all depends upon what they are used for and who controls them. Most religious people think reproductive genetic technologies are great-as long as they are used to further God's wishes, such as the elimination of disease. They are concerned that these technologies will be used for other purposes, like creating blue-eyed, blond-haired "perfect" children.

This is the sort of subtle moral conflict that to some extent already exists among religious and scientific elites and could become more pervasive among the religious public if genetic modification technologies continue to improve. Again, none of this is about knowledge, as the religious people are willing to conclude that scientists have their facts right about genetics and reproduction. What would be in conflict are subtle moral differences, such as scientists and the religious having different notions of what a disease is, with the scientists relying upon contemporary conceptions of disease and the religious on their interpretation of religious views. These subtle disagreements are fruitful territory for future scholars to examine.

\section{CONCLUSION}

In this chapter, I demarcated three types of moral conflict between religion and science, and used what social science data exists to try to evaluate such conflict. The first is conflict over whether science or religion will set the meaning and purpose of humanity. That is, at its most abstract, should we have faith in religion or faith 
in science? Evidence shows that religious Americans in general are in this type of conflict with science, and that conservative Protestants are even more strongly so.

A second type of moral conflict is over the moral teachings of scientists. Scientists typically do not think that they are promoting a particular morality, but in Chapter 5 we saw a wide range of evidence suggesting that the public will view scientists through a moral lens. That is what we also see in this chapter, with the evidence suggesting that conservative Protestants do not want scientists to be influential in moral debates in the public sphere, which suggests conflict. Moreover, conservative Protestants do not think of scientists as selflessly working on society's behalf, suggesting that they could also see scientists having moral interests.

A third type of moral conflict is over the technology that science empowers. Analysis shows that the most conservative of Protestants are increasingly in moral conflict with science over time, which I interpret to be a reflection of both religion and science becoming more concerned about technologies of the human body. Finally, I engage in fine-grained analysis of interviews with religious Americans of their views of reproductive genetic technologies. These show that religious Americans are not opposed to technology per se, but may be in subtle moral conflict with scientists now and in the future over these technologies. In the same way that Brooke's historical "complexity" thesis of the relationship between religion and science disrupted simple claims of universal knowledge conflict, the qualitative data reviewed in this chapter show that the moral relationship between religion and science is also a complex mix of consensus and conflict that depends on many situational factors. 